\title{
Financial Inclusion in Rural India: The role of Microfinance as a Tool
}

\author{
${ }^{1}$ Dr. Christabell. P. J. ${ }^{2}$ Vimal Raj. A \\ ${ }^{1}$ Assistant Professor, Department of Economics Government College for Women Thiruvananthapuram -695 514 \\ ${ }^{2}$ Research Scholar in Economics University Library University of Kerala Thiruvananthapuram
}

\begin{abstract}
The responsibility of meeting the credit needs in the rural areas of India was entrusted primarily with the cooperative sector and later to the commercial banks. One of the major objectives of the nationalization of major commercial banks in 1969/1980 was to improve the flow of formal institutional credit to rural households. Although these measures were ambitious and laudable, bank credit did not reach the poor people in adequate quantum. The financial sector reforms begun in 1992 have been systematically moving away from the social objective of the banking sector. The formal financial sector in India is shifting its focus from "mass banking" to "super-class banking". Though banking sector has witnessed tremendous changes in recent periods in terms of technological advancements, internet banking, online money transfers, etc, "financial exclusion" is a reality. It is in this context that the term "financial inclusion" gains importance and it is defined as the process of ensuring access to financial services and timely and adequate credit needed by vulnerable groups such as weaker sections and low income groups at an affordable cost. In countries with a large rural population like India, financial exclusion has a geographic and social dimension. Geographic exclusion is exposed through inaccessibility; distances and lack of proper infrastructure. Building an inclusive financial sector has gained growing global recognition bringing to the fore the need for development strategies that touch all lives, instead of a select few. The overall strategy for financial inclusion, especially amongst the poor and disadvantaged segments of the population should comprise ways and means to effect improvements within the existing formal credit delivery mechanism, as well as an evolution of new models for extending outreach, and a leverage on technology solutions to facilitate large scale inclusion. Only two to five percent of the 500 million poorest households in the world have access to institutional credit. Of which, women receive a disproportionately small share of credit from formal banking institutions. The Women's Self Help Group movement is bringing about a profound transformation in rural areas of India. Microfinance Institutions (MFIs) play a significant role in facilitating inclusion, as they are uniquely positioned in reaching out to the rural poor. Many of them operate in a limited geographical area, have a greater understanding of the issues specific to the rural poor, enjoy greater acceptability amongst the rural poor and have flexibility in operations providing a level of comfort to their clientele. The present paper deals with how the mechanism of microfinance can enable the financial inclusion of hitherto excluded population, especially the women, into the formal financial sector.
\end{abstract}

\section{Introduction}

The responsibility of meeting the credit needs in the rural areas of India was entrusted primarily with the cooperative banking sector until about the mid-1960s. As the technological developments in the agricultural sector started gathering momentum, it was expected that commercial banks would play an increasing role in the rural credit market through branch expansion and direct lending. One of the major objectives of the nationalisation of Indian commercial banks was the improvement of the flow of formal institutional credit into rural households, especially to the poor, thus relieving them of the burden of usurious debt.

The overriding objective of nationalization was the taking of banking to the 'masses'. The government envisaged that 40 percent of the total credit of the nationalised banks/commercial banks should be channelised to priority sectors (of which 18 percent was for agriculture and ten percent for weaker sections), groups or regions to support activities that were either considered to be socially beneficial or inherently risky and borrower groups that were likely to be marginalised in the credit markets, at lower rates of interest. This was an important step in the direction of asserting the developmental role of banks.

These measures had a strong impact on rural economy. The vast branch expansion of nationalised banks helped the people in remotest areas to have access to financial services. The growth and extension of rural credit displaced village moneylenders to a significant extent (Bell, 1990) and led to modest increases in aggregate crop output, sharp increases in the use of fertilizers and in investments in physical capital like tractors, pump sets and animal stocks. A substantial positive effect is seen in non-farm employment and output also (Binswanger and Khandker, 1992).

Although the banking system has experienced phenomenal growth in terms of geographical spread, deposit mobilisation and disbursal of credit in rural areas after nationalisation, bank credit remains by and large, 
inaccessible to the poor. The poor both in rural and urban areas do not have the necessary capabilities to approach and negotiate with formal financial institutions. The drive of very poor people to help themselves through self-employment is ignored by the formal financial sector. Because the very poor have not traditionally been recognised as creditworthy or able to save, they are not perceived by the conventional agencies as profitable clientele for credit.

Further, the rural credit system entrapped by the twin problems of high transaction cost and poor repayment performance reduces the profitability of rural branches of nationalised banks. The incompetence of management of individual banks also increased the non-viability of the rural credit delivery system (Analyst, 1993). The creditworthiness criteria adopted by institutional credit are alienating small farmers from borrowing as lending is closely linked to the landholding status of the borrower. The formal credit institutions neglected consumption needs of the poor and emphasised only on production credit. The spread of the system has been uneven across regions and wealth groups. The proportion of the poor obtaining credit from the banking system has been lower than their share in the total population. Moreover, there is widespread belief that the poor are unbankable. There are also internal problems such as absence of linkages of credit with marketing, investment credit having no provision for working capital. Inadequate staff and managerial deficiencies within the banking system have also been causing problems (Rajasekhar, 1994).

The financial sector reforms begun in 1992 were intended to liberalise the financial sector. But the proposed reforms have been systematically moving away from the social objective of the banking sector by abolishing concessional interest rates, insisting on collateral even for small borrowers and making large stipulated minimum balance compulsory for granting loans to small savers from the system (Mujumdar, 1995). In consequence, the number of small borrowal accounts has declined and it has resulted in misallocation of funds, especially diversion to investment from credit to the small borrower, expansion of foreign bank which only serves the elite in urban areas (Joshi, 1999). In short, the formal financial sector in India is shifting its focus from "mass banking" to "super-class banking".

In recent periods, banking sector witnessed tremendous changes in terms of technological advancements, internet banking, online money transfers, etc. But it is a reality that access to such technology is restricted only to certain segments of the society. Indeed, some trends, such as increasingly sophisticated customer segmentation technology have led to restricted access to financial services for some groups. There is a growing divide, with an increased range of personal finance options for a segment of high and upper middle income population and a significantly large section of the population who lack access to even the most basic banking services. This is termed "financial exclusion". These people, particularly, those living on low incomes, cannot access mainstream financial products such as bank accounts, credit, remittances and payment services, financial advisory services, insurance facilities, etc.

\section{Objectives}

1. To examine the extent of financial exclusion in rural India

2. To enquire into the role of microfinance in helping the rural population in the case of financial inclusion.

3. To study the extent of progress made by microfinance in rural India

4. To look into the challenges ahead for microfinance in India

\section{Methodology}

Secondary sources of data are used. Data published by various institutions such as Government of India, World Bank, Consultative Group to Assist the Poor (CGAP), Reserve Bank of India (RBI), National Bank for Agriculture and Rural Development (NABARD, State Level Bankers' Committee (SLBC), etc are used for the purpose of the present paper.

\section{Discussion of results}

The process of financial inclusion is an attempt to bring within the ambit of the organized financial system the weaker and vulnerable sections of society. Financial inclusion can be defined as the delivery of credit and other financial service at an affordable cost to the vast sections of the disadvantaged and low income groups. The objective of financial inclusion is to extend the scope of activities of the organized financial system to include, within its ambit, people with low incomes. Through graduated credit, attempts must be made to lift the poor so that they come out of poverty. Financial inclusion may, therefore, be defined as the process of enabling access to timely and adequate credit and other financial service by vulnerable groups, such as weaker sections and low income groups at affordable cost. The target for National Rural Financial Inclusion Plan (NRFIP) is to provide access to comprehensive financial services to atleast 50\% (55.77 million) of the excluded rural cultivator and noncultivator households, across different States by 2012 through' rural/ semi urban branches of Commercial Banks and Regional Rural Banks. 


\subsection{The Extent of Financial Exclusion in Rural India}

Based on the All Indian Debt Investment Survey 2002, 111.5 million households had no access to formal credit. It also showed that 17 million households were indebted to moneylenders. The Arjun Sengupta Report on financing enterprises in the unorganized sector has pointed out that only 2.4 million out of 58 million units in this sector (with investment of less than Rs 25000) have got credit from commercial banks. The AIDIS 2002 also showed that lower the asset class or income, higher the degree of exclusion. These findings are corroborated by Invest India Incomes and Savings Survey (2007). The survey showed that 32.8\% of households had borrowed from institutional sources and $67.2 \%$ had borrowed from non institutional sources. The survey also found that 70 per cent of earners in the annual income bracket of more than Rs.400,000 borrowed from institutional sources as compared with only 27.5 per cent in the case of earners in the income bracket of less than Rs.50,000.

Of the underprivileged sections of the society - farmers, small venders, agriculture or industrial laborers, people engaged in unorganized sector, unemployed people, women, children, old people and the physically challenged - only 40 per cent of the people have a check in account, 20 per cent have taken life insurance products, 0.6 per cent have taken non-life insurance products, only 2 per cent have access to credit cards. Geographically, only 5.2 per cent of the country's villages have a bank branch. (Kochhar, 2009)

Despite the vast network of rural branches, only 27 per cent of the total farm households are indebted to formal sources; of them, one third also borrow from informal sources. There are parts of the country where more than 95 per cent of the farm households do not get any credit from institutional or non institutional sources. Apart from the fast that exclusion itself is large, it also varies widely across regions, social groups and assets holdings. The poorer the group, the greater is the exclusion. There is evidence that farm debt is increasing much faster than farm incomes and the larger issue of the overhanging debt stock, as distinct from credit flow, has not even been on the agenda except of a few State governments. (Planning Commission, 2006). According to NSSO data in the situation assessment survey on "Indebtedness of Farmer households" (2003), 45.9 million farmer households in the country (51.4\%), out of a total of 89.3 million households do not access credit, either from institutional or non-institutional sources. Further, only $27 \%$ of total farm households are indebted to formal sources. (RBI, 2009)

\subsection{Microfinance and Financial Inclusion}

Since formal credit institutions rarely lend to the poor, special institutional arrangements become necessary to extend credit to those who have no collateral to offer. Microfinance, by providing small loans and savings facilities to those who have been excluded from commercial financial services, has been promoted as a key strategy for reducing poverty in all its forms by agencies all over the world. Microcredit has been defined as "programmes that provide credit for self-employment and other financial and business services (including savings and technical assistance) to very poor persons" (Micro Credit Summit, 1997). Nowadays, microfinance represents something more than microcredit - it also refers to savings, insurance, pawns and remittances, in sum to a much wider range of financial services (Tankha, 1999). In most cases, microcredit programmes offer a combination of services and resources to their clients in addition to usual credit for self-employment. Also, this is an effort to provide a bridge between formal financial markets and the informal groups in the formal microfinance initiatives.

The basic idea of microfinance is that poor people are ready and are willing to pull themselves out of poverty if given access to economic inputs. The need for informality in credit delivery and easy access is demonstrated by the fact that Self Help Groups (SHGs) and Microfinance Institutions (MFIs) constitute the fastest growing segment in recent years in reaching out to small borrowers. Micro-finance is a new development in which Indian institutions have acquired considerable expertise and where up-scaling holds great promise both to expand the nature of financial services offered to micro enterprises and to make these the springboard for entrepreneurial development. (Planning Commission, 2006)

The SHG movement is bringing about a profound transformation in rural areas of India. MFIs play a significant role in facilitating inclusion, as they are uniquely positioned in reaching out to the rural poor. Many of them operate in a limited geographical area, have a greater understanding of the issues specific to the rural poor, enjoy greater acceptability amongst the rural poor and have flexibility in operations providing a level of comfort to their clientele. It is roughly estimated that there are about 1,000 NGO-MFIs and more than 20 Company facilitating the activities in all over India. There are today over 22 lakh such groups linked with banks. The objective of the country is to enrol at least $50 \%$ of all rural women in India as members of SHGs over the next five years and link these SHGs to banks.

\subsection{Progress of Microfinance in India}

The institutions which engage in microfinance services in India follow three types of approaches namely

i. The Grameen Bank approach

ii. The Cooperative Societies (which are members of a cooperative bank) approach 
iii. The SHG Programme approach.

In the four years between 2003 and 2007, small borrower bank accounts (credit) i.e. upto Rs 25,000 increased marginally from 36.9 million to 38.6 million, while SHGs' borrowing members grew from 10 million to 40.5 million and MFIs' borrowers grew from 1.1 million to 8 million. In 2007-08, MFIs have added 6 million clients increasing their outreach to 14 million as per data brought out by Sa Daan.

An innovative scheme in rural delivery system launched by NABARD is the linking of SHGs of the poor with banks and bulk lending through NGOs. NABARD considers SHGs a pre-microenterprise stage for a majority of the rural population. The linkage project envisages active involvement of NGOs who play a crucial role in formation, nurturing, stabilising and guiding the SHGs into cohesive and dynamic groups inculcating the habits of thrifts and credit management and ultimately establishing linkage with the banks. Under the SHG-bank linkage programme, three linkage models have broadly emerged. Under the first model, banks directly link SHGs without the intervention of the NGOs. In the second model, banks provide credit to SHGs and NGOs act as Self Help Promoting Institutions (SHPIs). Under the third model, NGOs act both as SHPIs and financial intermediaries for channelising credit from banks to SHGs.

The SHG-Bank Linkage Programme implemented by commercial banks, RRBs and cooperative banks has emerged as the major micro- finance programme in the country. Under the SHG-Bank Linkage Programme, as on March 31, 2009, 61,21,147 SHGs held savings bank accounts with total savings of Rs 5,545.62 crore as against 50,09,794 SHGs with savings of Rs 3,785.39 crore as on March 31, 2008. Thus more than 8.06 crore poor households were associated with banking agencies under the SHG- Bank Linkage Programme. The table 1 clearly shows the progress under SHG Bank Linkage programme in India.

Table 1 Progress under SHG-Bank Linkage

\begin{tabular}{|c|c|c|c|c|c|c|}
\hline \multirow{2}{*}{ Year } & \multicolumn{4}{|c|}{ New SHGs financed by banks Bank loan } & Bank loan \\
\cline { 2 - 6 } & \multicolumn{2}{|c|}{ During the year } & \multicolumn{2}{c|}{ Cumulative during the year } & Cumulative \\
& No. & Growth (\%) & No. & Amount & Growth (\%) & amount \\
\hline $2002-03$ & $2,55,882$ & 29 & $7,17,360$ & $1,022.34$ & 87 & $2,048.68$ \\
\hline $2003-04$ & $3,61,731$ & 41 & $10,79,091$ & $1,855.53$ & 81 & $3,904.21$ \\
\hline $2004-05$ & $5,39,365$ & 49 & $16,18,456$ & $2,994.25$ & 62 & $6,898.46$ \\
\hline $2005-06$ & $6,20,109$ & 15 & $22,38,565$ & $4,499.09$ & 50 & $11,397.55$ \\
\hline $2006-07$ & $11,05,749^{*}$ & -- & $28,94,505$ & $6,570.39$ & -- & $12,366.49$ \\
\hline $2007-08$ & $12,27,770^{*}$ & 11 & $36,25,941$ & $8,849.26$ & 35 & $16,999.90$ \\
\hline $2008-09 \#$ & $16,09,586^{*}$ & 31.1 & $42,24,338$ & $12,256.51$ & 38.5 & $22,679.85$ \\
\hline
\end{tabular}

* from 2006-07 onwards, data in respect of number of SHGs financed by banks and bank loans are inclusive of SHGs financed under the Swarnajayanti Gram Swarozgar Yojana (SGSY) and the existing groups receiving repeat loans. Owing to this change, NABARD discontinued compilation of data on cumulative basis from 2006-07. As such data from 2006-07 onwards are not comparable with the data of the previous years. \# Provisional

Source: GoI, 2009

As on March 31,2009, commercial banks had the maximum share of SHG savings with savings of $35,49,509$ SHGs ( 58 per cent) amounting to Rs $2,772.99$ crore (50 per cent); this was followed by RRBs with savings bank accounts of 16,28,588 SHGs (26.6 per cent) and savings amount of Rs1,989.75 crore (35.9 per cent) and cooperative banks with savings bank accounts of 9,43,050 SHGs (15.4 per cent) and savings amount of Rs 782.88 crore ( 14.1 per cent).

The share of the Swarnajayanti GramSwarozgar Yojana (SGSY) in SHG savings accounts was $15,05,581$ SHGs, forming 25 per cent of the total SHGs having savings accounts in banks. During 2008-09, the average savings per SHG with all banks increased from Rs 7,556 as on March 31, 2008 to Rs 9,060 as on March 31, 2009, varying between a high of Rs 12,218 per SHG with RRBs and a low of Rs 7,812 per SHG with commercial banks. As on March 31, 2009, the share of women SHGs in total SHGs with savings bank accounts was $48,63,921$, accounting for 79.46 per cent as compared to the previous year's share of 79.56 per cent. During 2008-09, banks financed 16,09,586 SHGs, including repeat loans to existing SHGs, as against 12,27,770 SHGs during 2007-08 - a growth of 31.1 per cent (number of SHGs).

As on March31, 2009, 42,24,338 SHGs had outstanding (cumulative) bank loans of Rs 22,679.85 crore as against 36,25,941 SHGs with outstanding bank loans of Rs16,999.90 crore as on March 31, 2008(Table 5.9). This included 9,76,887 SHGs (6.5 percent) with outstanding bank loans of Rs 5,861.72crore (21.7per cent) under the SGSY as against 9,16,978 SHGs with outstanding bank loans of Rs 4,816.87 crore as on March 31, 2008. Commercial banks had the maximum share of around 70 percent of outstanding bank loans to SHGs followed by RRBs with a share of 23 per cent and cooperative banks with the balance. As on March 31, 2009, the average bank loan outstanding per SHG was Rs53,689 as against Rs 46,884 as on March 31, 2008. It varied from a high of Rs 57,037 per SHG in the case of commercial banks to a low of Rs 31,460 per SHG in the case of cooperative banks. 


\subsection{Challenges Ahead for Microfinance in India}

An evaluation of SHGs carried out by the regional offices (ROs) of the Reserve Bank revealed that there was scope for improvement in the area of maintenance of books of accounts. It also brought out that rotation of group leaders was generally not followed by SHGs. However, other best practices like strict adherence to attendance of group meetings, recording minutes of the meetings and prompt repayment of bank loans were being followed. The momentum of growth in the micro-finance sector has brought into focus the importance of regulating the sector to function in an efficient and orderly manner. There would be need for greater transparency in their functioning and for facilitating their reach to un-banked population of the country Interest rates in the microfinance sector have to be significantly higher than in the banking sector reflecting the much higher cost of doing business. This attracts criticism but it is important to remember that most microfinance institutions charge rates which are much lower than rates charged by money lenders. Borrowers stand to benefit from the experience of micro-finance institutions as these provide competition to money lenders. (Planning Commission, 2006)

Over the past two decades, institutions that make microloans to low-income borrowers in developing and transition economies have focused increasingly on making their operations financially sustainable by charging interest rates that are high enough to cover all their costs. They argue that doing so will best ensure the permanence and expansion of the services they provide. Sustainable (i.e., profitable) microfinance providers can continue to serve their clients without needing ongoing infusions of subsidies, and can fund exponential growth of services for new clients by tapping commercial sources, including deposits from the public. MFIs on average have higher returns on assets than commercial banks do, but MFIs produce lower returns on equity for their owners. The median return on MFI owners' equity in 2006 was moderate- 12.3 percent, roughly 4 percent lower than the return for banks. (Rosenberg, et al.)

There have been incidents of state governments imposing restrictions on micro-finance institutions in a manner which does not reflect an appreciation of the realities on the ground. Excessive regulation and control of this sector may be particularly dangerous as it can prevent the development of a healthy and competitive microfinance sector which could compete with usurious money lenders. (Planning Commission, 2006)

\section{Conclusion}

Finance is the lubricant, which oils the wheels of development. All economies rely upon the intermediary function of finance to transfer resources from savers to investors. In market economies, this function is performed by commercial banks, financial institutions and capital markets. In many developing countries, capital markets are at a rudimentary stage, and commercial banks are reluctant to lend to the poor largely because of the lack of collateral and high transaction costs. The poor would borrow relatively small amounts, and the processing and supervision of lending to them would consume administrative costs disproportionate to the amount of lending.

Extending the reach of financial services to the poor through new technologies and simplified branch regulations hold promise. Bringing financial services to rural clients is the biggest challenge in the quest for broad-based financial inclusion. Often the main barrier to financial inclusion in rural areas is the great distances that rural residents must travel to reach a bank branch. Poor infrastructure and telecommunications, and heavy branch regulation, also restrict the geographical expansion of bank branch networks. In many developing countries there are fewer bank branches per rural resident than per urban resident. Non bank financial institutions like microfinance institutions help to fill this gap. Even though, in India, the microfinance model extends credit and savings to the poor, the challenges faced by the industry has to be rectified in due course for the effective working of the model.

\section{References}

[1] Rajasekhar, D., Savings And Credit Systems Of The Poor: Some Non-Governmental Organisation (NGO) Experiences, Bangalore, NOVIB And HIVOS, 1994

[2] Reserve Bank Of India (RBI), Report Of The Working Group To Review The Business Correspondent Model, Mumbai, 2009.

[3] Tankha, Ajay. "Some NGO Dilemmas In Reaching The Poorest With Microfinance." Search Bulletin 14(1), 1999, Pp.73-79.

[4] Rosenberg, Richard, Adrian Gonzalez, And Sushma Narain, "Are Microcredit Interest Rates Excessive?",. CGAP Brief, Washington, 2009

[5] Analyst, "Myth Of Non-Viability Of Rural Branches", Economic And Political Weekly 28(18), 1993, Pp. 853-854:

[6] Bell, Clive, "Interactions Between Institutional And Informal Credit Agencies In Rural India", The World Bank Economic Review 4(3), 1990, Pp. 297-327.

[7] Binswanger, Hans, And S. Khandker, The Impact Of Formal Finance On The Rural Economy Of India, WPS 949, Agricultural And Rural Development Department, 1992.

[8] Government Of India (Goi), Economic Survey 2009, New Delhi, 2010.

[9] Joshi, P. N., "Banking Sector Reform - The Other Side Of The Coin", Economic And Political Weekly, 34(4), 1999, Pp.797-798.

[10] Kochhar, Sameer, Speeding Financial Inclusion, New Delhi; Academic Foundation, 2009.

[11] Mujumdar, N. A., "New Banking Culture And Small Borrower", Economic And Political Weekly 30(35), 1995, Pp.2169-2170.

[12] Planning Commission, Towards Faster And More Inclusive Growth: An Approach To The 11th Five Year Plan, Government Of India, New Delhi, 2006. 